\title{
Effect of adefovir dipivoxil on $T$ cell immune function in the treatment of chronic hepatitis $B$ and hepatocirrhosis
}

\author{
LITING TIAN $^{1 *}$, QILIN FU ${ }^{1 *}$ and FU HUANG ${ }^{2}$ \\ Departments of ${ }^{1}$ Liver Disease, and ${ }^{2}$ Gastroenterology, Shaanxi Provincial Hospital of \\ Traditional Chinese Medicine, Xi'an, Shaanxi 710003, P.R. China
}

Received May 2,2016; Accepted August 18, 2016

DOI: 10.3892/etm.2016.3623

\begin{abstract}
The aim of the present study was to investigate the $\mathrm{T}$ cell immune function in chronic hepatitis $\mathrm{B}$ hepatocirrhosis patients at the compensated and decompensated stage following treatment with adefovir dipivoxil. A total of 104 patients diagnosed with hepatitis B hepatocirrhosis during the period from October 2013 to October 2014 were enrolled in the study. Among the cases, there were 56 cases at compensated stage, and another 48 at decompensated stage. Adefovir dipivoxil was administered for antiviral therapy $(10 \mathrm{mg} / \mathrm{time}$, 1 time/day, for a total of 24 weeks), and we compared the virus disappearance rate, liver function improvement and $\mathrm{T}$ cell immune function between the two groups before and after treatment. The difference between the virus disappearance rate in the two groups was not statistically significant $(\mathrm{P}>0.05)$. The decreased level of ALT decrease in the compensated group was significantly higher than that in the decompensated group, while the increased level of albumin in the compensated group was significantly higher as well. The differences showed statistical significance $(\mathrm{P}<0.05)$. After treatment, the level of $\mathrm{CD}^{+}$and $\mathrm{CD}^{+} / \mathrm{CD}^{+}$ratio were higher than before treatment, while the level of $\mathrm{CD}^{+}$was lower after treatment than before treatment in the two groups. The differences all showed statistical significance $(\mathrm{P}<0.05)$. The $\mathrm{CD} 4^{+} \mathrm{CXCR} 5^{+}$ $\mathrm{T}$ follicular helper (TFH) cell level in the two groups was higher after treatment, as was interleukin- 2 and interferon- $\gamma$. The differences all showed statistical significance $(\mathrm{P}<0.05)$. As for comparison between groups, the difference had no statistical significance $(\mathrm{P}>0.05)$. Adefovir dipivoxil treatment can improve $\mathrm{T}$ cell immune function at the compensated and decompensated stages in chronic hepatitis B hepatocirrhosis patients. This may be associated with virus disappearance and liver function improvement.
\end{abstract}

Correspondence to: Dr Fu Huang, Department of Gastroenterology, Shaanxi Provincial Hospital of Traditional Chinese Medicine, No.4 Xihuamen Street, Xi'an, Shaanxi 710003, P.R. China

E-mail: huangfu7059@163.com

\section{${ }^{*}$ Contributed equally}

Key words: adefovir dipivoxil, chronic hepatitis B hepatocirrhosis, virus disappearance rate, follicular helper $\mathrm{T}$ cell

\section{Introduction}

The nucleotide analog adefovir dipivoxil has a clear-cut effect in treating acute and chronic hepatitis B hepatocirrhosis and has shown many advantages, such as clinical strengths of low drug resistance and light side effects $(1,2)$. Apart from interfering with the DNA transcription directly, adefovir dipivoxil can adjust the immune function of the body, including cellular and humoral immunity (3). A previous study indicated that adefovir dipivoxil can improve the level of $\mathrm{CD}^{+}$and $\mathrm{CD}_{4}^{+} /$ $\mathrm{CD}^{+}$and lower the level of $\mathrm{CD}^{+}$, thus playing an important role in antivirus activity and reversal of hepatic fibrosis (4). Based on this, we hypothesized that adefovir dipivoxil may be able to adjust and interfere with the $\mathrm{T}$ cell immune function in chronic hepatitis B hepatocirrhosis patients. The development and progression of hepatitis B virus (HBV)-related hepatic cirrhosis involves not only damage to liver cells and the body's immune system induced by viral replication but also virus cleaning and self-repairing by the body (5). The extent of liver function lesions is not consistent with the process of viral replication (6). The immune system, especially $\mathrm{T}$ cells, plays a vital role in the process of viral replication. To date, few studies have investigated the immune capacity of T cells at different states of liver function and whether the metabolism and activation capacity of different antiviral drugs are consistent $(7,8)$.

The purpose of the present study was to investigate the effects of adefovir dipivoxil on patients with HBV-related hepatocirrhosis at different stages and to explore the regulating capacity of adefovir dipivoxil on immune function of T lymphocytes.

\section{Patients and methods}

Patients. A total of 104 patients diagnosed with hepatitis B hepatocirrhosis during the period from October 2013 to October 2014 were enrolled in the study. Inclusion and exclusion criteria were as follows. Inclusion standards include: i) age, $\geq 18$ and $\leq 75$ years; ii) fulfills the diagnostic criteria of liver cirrhosis and stage is known; and iii) receives antivirus treatment for the first time. Exclusion standards include: i) patients with non-hepatitis B hepatocirrhosis, alcoholic hepatitis B, autoimmune liver disease, development into cancer; ii) patients presenting complications of serious functional 
Table I. Virus quantity and comparison of the disappearance rate.

\begin{tabular}{|c|c|c|c|c|c|c|c|c|}
\hline \multirow[b]{2}{*}{ Groups } & \multicolumn{4}{|c|}{ HBV DNA level $\left(10^{4}\right.$ copies $\left./ \mathrm{ml}\right)$} & \multicolumn{4}{|c|}{ HBsAg, HBeAg, HBcAb-positive (cases, \%) } \\
\hline & $\begin{array}{l}\text { Before } \\
\text { treatment }\end{array}$ & $\begin{array}{c}\text { After } \\
\text { treatment }\end{array}$ & $\mathrm{t}$ & P-value & $\begin{array}{l}\text { Before } \\
\text { treatment }\end{array}$ & $\begin{array}{c}\text { After } \\
\text { treatment }\end{array}$ & $\chi^{2}$ & P-value \\
\hline $\begin{array}{l}\text { Compensated } \\
(\mathrm{n}=56)\end{array}$ & $23.4 \pm 5.2$ & $2.2 \pm 0.3$ & 68.624 & $<0.001$ & $49(87.5)$ & $11(19.6)$ & 51.836 & $<0.001$ \\
\hline $\begin{array}{l}\text { Decompensated } \\
(\mathrm{n}=48)\end{array}$ & $23.6 \pm 6.3$ & $2.5 \pm 0.4$ & 66.462 & $<0.001$ & $45(93.8)$ & $12(25.0)$ & 47.028 & $<0.001$ \\
\hline $\mathrm{t}\left(\chi^{2}\right)$ & 0.547 & 0.109 & & & 0.554 & 0.431 & & \\
\hline P-value & 0.326 & 0.748 & & & 0.457 & 0.512 & & \\
\hline
\end{tabular}

HBV, hepatitis B virus; HBsAg, hepatitis B surface antigen; HBeAg, hepatitis B e antigen; HBcAb, hepatitis B core antibody.

Table II. Comparison of liver function improvement.

\begin{tabular}{|c|c|c|c|c|c|c|c|c|c|c|}
\hline \multirow[b]{2}{*}{ Groups } & \multicolumn{5}{|c|}{$\operatorname{ALT}(\mathrm{U} / \mathrm{l})$} & \multicolumn{5}{|c|}{ Albumin (g/l) } \\
\hline & $\begin{array}{c}\text { Before } \\
\text { treatment }\end{array}$ & $\begin{array}{c}\text { After } \\
\text { treatment }\end{array}$ & $\mathrm{t}$ & P-value & Improvement & $\begin{array}{l}\text { Before } \\
\text { treatment }\end{array}$ & $\begin{array}{c}\text { After } \\
\text { treatment }\end{array}$ & $\mathrm{t}$ & P-value & Improvement \\
\hline $\begin{array}{l}\text { Compensated } \\
(\mathrm{n}=56)\end{array}$ & $46.5 \pm 4.7$ & $36.5 \pm 3.3$ & 3.648 & 0.041 & $11.6 \pm 2.7$ & $43.7 \pm 6.2$ & $60.2 \pm 5.2$ & 4.827 & 0.038 & $18.2 \pm 4.4$ \\
\hline $\begin{array}{l}\text { Decompensated } \\
(\mathrm{n}=48)\end{array}$ & $77.8 \pm 6.9$ & $69.2 \pm 5.4$ & 3.325 & 0.042 & $7.5 \pm 3.3$ & $22.5 \pm 3.4$ & $35.4 \pm 3.9$ & 4.629 & 0.039 & $11.6 \pm 3.2$ \\
\hline $\mathrm{t}$ & 4.321 & 4.627 & & & 5.624 & 5.026 & 5.424 & & & 5.794 \\
\hline P-value & 0.039 & 0.036 & & & 0.027 & 0.034 & 0.032 & & & 0.025 \\
\hline
\end{tabular}

ALT, alanine aminotransferase.

disorder of the heart, liver, kidney or other organs; adefovir dipivoxil cannot be tolerated and have no drug resistance; and iii) patients who do not abide by the study regulations or provide full information, or reject to participate in the study.

Hepatitis B hepatocirrhosis was divided into the compensated stage and decompensated stage according to the disease stage. Fifty-six patients were in the compensated stage: 30 males and 26 females, aged from 37 to 66 years with an average age of $49.8 \pm 10.3$ years. The course of disease in this group ranged from 1 month to 10 years, with an average of $3.2 \pm 0.6$ years. Forty-eight patients were in decompensated stage: 25 males and 23 females, aged from 36 to 74 years with an average age of $50.2 \pm 12.2$ years. The course of disease in this group ranged from 6 months to 13 years, with an average of $3.9 \pm 1.2$ years. No statistical significance was found in terms of gender, age and disease course between these two groups $(\mathrm{P}>0.05)$.

Methods. Proper treatment was administered to the patients. For example, anemia patients with $<60 \mathrm{~g} / 1$ hemoglobin were given a blood transfusion. Patients with low protein received an external protein supplement. The patients received a healthy diet and were well-rested with protection of the liver with lowering of transaminase level. Adefovir dipivoxil (10 mg/time, 1 time/ day, for a total of 24 weeks; Zhengda Tianqing Pharmaceutical
Co., Ltd., Nanjing, China) was administered as antivirus treatment. A routine blood examination, liver and kidney function as well as the virual replication level were regularly supervised.

Observation index and test method. Differences in the virus disappearance rate, liver function improvement and $\mathrm{T}$ cell immune function were analyzed. Virus disappearance occurs when positive $\mathrm{HBsAg}$, HBeAg, HBcAb levels become negative. By testing the ALT level before and after treatment and the level of albumin, the condition of the liver function can be assessed. The ELISA method was applied for HBV serum marker. The kit was provided by Yingke Xinchuang Technology Co., Ltd. (Xiamen, China). Olympus full-automatic analyzer AU5400 SOP was applied as a standard in testing the liver function. The HBV DNA quantitative test uses the fluorescent quantitative polymerase chain reaction method. The kit was provided by DaAn Gene Co., Ltd. of Sun Yat-Sen University (Guangzhou, China). The lowest limit of detection is $10^{3}$ copies $/ \mathrm{ml}$. The $\mathrm{T}$ cell immune function was reflected by the level of $\mathrm{CD}^{+}, \mathrm{CD}^{+}, \mathrm{CD}^{+} / \mathrm{CD}^{+}$and $\mathrm{CD} 4^{+} \mathrm{CXCR}^{+}$ $\mathrm{T}$ follicular helper (TFH) cells, interleukin (IL)-2 and interferon (IFN) $-\gamma$. The test for the subpopulation of $\mathrm{T}$ cells was carried out using EPICS XL flow cytometry analyzer and System II software (both from Beckman Coulter, Inc., Brea, CA, USA). 
Table III. Comparison of $\mathrm{CD}^{+}$and $\mathrm{CD}^{+}$levels and $\mathrm{CD} 4^{+} / \mathrm{CD}^{+}$ratio.

\begin{tabular}{|c|c|c|c|c|c|c|c|c|c|c|c|c|}
\hline \multirow[b]{2}{*}{ Groups } & \multicolumn{4}{|c|}{$\mathrm{CD}^{+}$} & \multicolumn{4}{|c|}{$\mathrm{CD}^{+}$} & \multicolumn{4}{|c|}{$\mathrm{CD}^{+} / \mathrm{CD}^{+}{ }^{+}$} \\
\hline & $\begin{array}{l}\text { Before } \\
\text { treatment }\end{array}$ & $\begin{array}{c}\text { After } \\
\text { treatment }\end{array}$ & $\mathrm{t}$ & P-value & $\begin{array}{l}\text { Before } \\
\text { treatment }\end{array}$ & $\begin{array}{c}\text { After } \\
\text { treatment }\end{array}$ & $\mathrm{t}$ & P-value & $\begin{array}{c}\text { Before } \\
\text { treatment }\end{array}$ & $\begin{array}{c}\text { After } \\
\text { treatment }\end{array}$ & $\mathrm{t}$ & P-value \\
\hline $\begin{array}{l}\text { Compensated } \\
(\mathrm{n}=56)\end{array}$ & $32.4 \pm 3.2$ & $41.5 \pm 4.3$ & 5.123 & 0.027 & $26.8 \pm 3.6$ & $21.4 \pm 2.5$ & 4.714 & 0.033 & $1.3 \pm 0.3$ & $2.4 \pm 0.5$ & 6.632 & 0.024 \\
\hline $\begin{array}{l}\text { Decompensated } \\
(\mathrm{n}=48)\end{array}$ & $30.5 \pm 3.1$ & $39.8 \pm 3.8$ & 5.624 & 0.023 & $27.7 \pm 3.4$ & $19.9 \pm 2.4$ & 4.623 & 0.035 & $1.1 \pm 0.2$ & $2.2 \pm 0.4$ & 6.325 & 0.026 \\
\hline $\mathrm{t}$ & 0.329 & 0.621 & & & 0.748 & 0.936 & & & 0.203 & 0.417 & & \\
\hline $\mathrm{P}$-value & 0.528 & 0.749 & & & 0.419 & 0.537 & & & 0.636 & 0.958 & & \\
\hline
\end{tabular}

Table IV. Comparison of CD $4{ }^{+} \mathrm{CXCR}^{+}$TFH cell, IL- 2 and IFN- $\gamma$ levels.

\begin{tabular}{|c|c|c|c|c|c|c|c|c|c|c|c|c|}
\hline \multirow[b]{2}{*}{ Groups } & \multicolumn{4}{|c|}{$\mathrm{CD}^{+} \mathrm{CXCR}^{+} \mathrm{TFH}$ cells $(\%)$} & \multicolumn{4}{|c|}{$\mathrm{IL}-2$ (ng/ml) } & \multicolumn{4}{|c|}{$\mathrm{IFN}-\gamma(\mathrm{pg} / \mathrm{ml})$} \\
\hline & $\begin{array}{c}\text { Before } \\
\text { treatment }\end{array}$ & $\begin{array}{c}\text { After } \\
\text { treatment }\end{array}$ & $\mathrm{t}$ & P-value & $\begin{array}{c}\text { Before } \\
\text { treatment }\end{array}$ & $\begin{array}{c}\text { After } \\
\text { treatment }\end{array}$ & $\mathrm{t}$ & P-value & $\begin{array}{c}\text { Before } \\
\text { treatment }\end{array}$ & $\begin{array}{c}\text { After } \\
\text { treatment }\end{array}$ & $\mathrm{t}$ & P-value \\
\hline $\begin{array}{l}\text { Compensated } \\
(\mathrm{n}=56)\end{array}$ & $21.6 \pm 4.2$ & $29.7 \pm 3.6$ & 4.785 & 0.039 & $45.7 \pm 6.9$ & $89.6 \pm 10.2$ & 5.928 & 0.027 & $67.8 \pm 14.5$ & $102.4 \pm 22.5$ & 5.624 & 0.033 \\
\hline $\begin{array}{l}\text { Decompensated } \\
(\mathrm{n}=48)\end{array}$ & $18.8 \pm 3.7$ & $26.5 \pm 3.2$ & 4.628 & 0.041 & $43.2 \pm 6.3$ & $85.5 \pm 11.3$ & 5.627 & 0.029 & $63.4 \pm 15.3$ & $93.7 \pm 20.3$ & 5.327 & 0.037 \\
\hline $\mathrm{t}$ & 0.625 & 0.364 & & & 0.747 & 0.858 & & & 0.758 & 0.629 & & \\
\hline P-value & 0.424 & 0.527 & & & 0.624 & 0.235 & & & 0.231 & 0.412 & & \\
\hline
\end{tabular}

IL, interleukin; IFN, interferon; TFH, follicular helper.

Statistical analysis. SPSS statistics 19.0 was applied to analyze the data. The measurement data were expressed as the mean \pm standard deviation. The t-test was carried out to analyze differences between groups while the unit was number of cases or percentage. The $\chi^{2}$ test was applied for inter-group comparison. $\mathrm{P}<0.05$ was considered to indicate a statistically significanct difference.

\section{Results}

Virus quantity and comparison of the viral disappearance rate. The difference in the HBV DNA quantitative level of the the compensated and decompensated stage groups before and after treatment of adefovir dipivoxil, as well as the positive rate of HBsAg, HBeAg and $\mathrm{HBcAb}$ did not show statistical significance $(\mathrm{P}<0.05)$. After treatment, the HBV DNA quantitative level and the positive rate of $\mathrm{HBsAg}, \mathrm{HBeAg}$ and $\mathrm{HBcAb}$ were obviously decreased, showing statistical significant differences $(\mathrm{P}<0.05)$. Yet, there were no statistically significant differences in inter-group comparison (Table I).

Comparison of liver function improvement. The altered level of ALT and albumin before and after treatment represented liver function improvement. The liver function in both groups was improved after treatment. The ALT improvement in the compensated group was obviously higher than that noted in the decompensated group, while the increase in albumin in the compensated group was significantly obvious as well. The differences showed statistical significance $(\mathrm{P}<0.05)$ (Table II).

Comparison of $T$ cell immune function. Before adefovir dipivoxil treatment, the difference in $\mathrm{T}$ cell immune function between the two groups showed no statistical significance. After treatment, the level of $\mathrm{CD}^{+}$and $\mathrm{CD}^{+} / \mathrm{CD}^{+}$were higher than before treatment, while the level of $\mathrm{CD}^{+}$became lower. The differences showed statistical significance $(\mathrm{P}<0.05)$. The $\mathrm{CD}^{+} \mathrm{CXCR}^{+} \mathrm{TFH}$ cell levels in the two groups were higher after treatment, as were IL- 2 and IFN- $\gamma$. The differences showed statistical significance $(\mathrm{P}<0.05)$. As for comparison between groups, the difference was not statistically significant $(\mathrm{P}>0.05)$ (Tables III and IV).

\section{Discussion}

The pathogenesis of chronic hepatitis B combined with hepatic cirrhosis is complex. In addition to the pathogenic effects of the virus, immune function disturbance also plays an important role. The immune response not only removes viruses, but also causes immune injury to hepatic cells, and may even cause virus mutation (9). The balance system of T lymphocyte subsets plays an important role in the removal of HBV (10).

$\mathrm{CD}^{+} \mathrm{T}$ lymphocytes identify exogenous antigenic peptides presented by MHC-II molecules, and then mainly differentiate into Th cells after activation (11). $\mathrm{CD}^{+} \mathrm{T}$ lymphocytes identify 
endogenous antigenic peptides presented by MHC-I molecules, and then mainly differentiate into CTL cells after activation (11). After the body is infected by HBV, the virus replicates in host cells and produces viral proteins (12). MHC-I molecules in cells combine with these proteins selectively to form complexes. These complexes are identified by specific antigens of $\mathrm{T}$ lymphocytes, which then activate $\mathrm{CD} 8^{+} \mathrm{T}$ lymphocytes which cause injury to hepatic cells (13). At the same time, $\mathrm{CD} 4^{+} \mathrm{T}$ lymphocytes mediate activation of B lymphocyte by MHC-II molecules on their surfaces, and promote B lymphocytes to produce anti-HBs which helps to clear HBV (14). This is the major reason why HBV causes injury to hepatic cells, and this is also the major mechanism involved in the host removal of the virus in the cells. Cell levels of $\mathrm{CD}^{+}$and $\mathrm{CD}^{+}$of T lymphocyte subsets in peripheral blood and the ratio of $\mathrm{CD}^{+} /$ $\mathrm{CD} 8^{+}$reflect the cellular immunity state of the body. Changes in $\mathrm{T}$ lymphocyte subsets in peripheral blood of patients with chronic hepatitis B reflect immunopathological changes in the patient cellular immunity (15).

Moreover, recent research has reported that $\mathrm{T}$ follicular helper (TFH) cells are the main T-cell subset that instruct B helper cells to produce antibody (16). These cells are located in lymph follicles and colocalized and interacted with B cells. They help B cells to participate in humoral immune response by continuously expressing membrane surface molecules such as CXCR5/ICOS/PD-1 and producing cytokines including IL-21. Adefovir dipivoxil is a purine derivative. It is hydrolyzed to dissociated adefovir by esterase quickly after oral intake. It then enters portal veins and the systemic circulation. It can be bisphosphonated to an active metabolite which is adefovir dipivoxil bisphosphonate by cellular kinases. Adefovir dipivoxil bisphosphonate competes with the natural substrate deoxyadenosine triphosphate (dATP) to inhibit the activity of HBV DNA polymerase and integrates it into the viral DNA strand to stop it from synthesis and inhibition of virus replication (17). In addition, adefovir is able to induce endogenous INF, increase natural killer cell activity and stimulate the body's immune response. Therefore, it has strong anti-HBV function and it is a safe and effective medicine for decompensated liver cirrhosis patients (18).

The present study is innovative as it explores the immune function of T lymphocytes when B liver cirrhosis patients in the compensated and decompensated period are treated with adefovir dipivoxil. The results showed that differences in the virus negative conversion ratio in the two groups did not achieve statistical significance; for the compensated group, the decreased level of ALT and increased level of albumin were obviously higher than those in the decompensated period and the differences were statistically significant. After treatment, the level of $\mathrm{CD}^{+}$and the $\mathrm{CD} 4^{+} / \mathrm{CD}^{+}$ratio in the two groups were higher than before treatment while the level of $\mathrm{CD}^{+}$was lower, however, no statistical significance was noted regarding differences between the two groups. $\mathrm{CD} 4{ }^{+} \mathrm{CXCR} 5^{+} \mathrm{TFH}$ cell, IL-2 and IFN- $\gamma$ levels were higher than before treatment but differences were not statistically significant between groups. In conclusion, adefovir dipivoxil can improve the immune function of $\mathrm{T}$ lymphocytes in chronic hepatitis $\mathrm{B}$ hepatocirrhosis patients in the compensated and decompensated periods, which may be related to negative conversion of the virus and improvement in liver function.

\section{References}

1. Horváth G, Hunyady B, Gervain J, Lengyel G, Makara M, Pár A, Szalay F, Telegdy L and Tornai I: Diagnosis and treatment of chronic hepatitis B and D. Hungarian National Consensus Guideline. Orv Hetil (Suppl 155): 25-36, 2014 (In Hungarian).

2. Peng H, Liu J, Yang M, Tong S, Yin W, Tang H, Hu P, Hu H and Ren H: Efficacy of lamivudine combined with adefovir dipivoxil versus entecavir monotherapy in patients with hepatitis B-associated decompensated cirrhosis: a meta-analysis. J Clin Pharmacol 54: 189-200, 2014.

3. Zhang L and Chang Y: Experimental study on effect of Dahuang Zhechong wan combined with adefovir dipivoxil in preventing hepatic fibrosis in patients with chronic hepatitis B. Zhongguo Zhong Yao Za Zhi 37: 862-864, 2012 (In Chinese).

4. Liu Y, Wang C, Zhong Y, Chen L, Li X, Ji D, Wang H, Xin S, Zoulim F and Xu D: Evolution and suppression of HBV strains with multidrug resistance to lamivudine, adefovir dipivoxil and entecavir in a patient with chronic hepatitis B. Antivir Ther 15: 1185-1190, 2010.

5. Zhu D, Liu L, Yang D, Fu S, Bian Y, Sun Z, He J, Su L, Zhang L, Peng $\mathrm{H}$, et al: Clearing persistent extracellular antigen of hepatitis B virus: an immunomodulatory strategy to reverse tolerance for an effective therapeutic vaccination. J Immunol 196: 3079-3087, 2016

6. Wang GL, Liu Y, Qiu P, Zhou SF, Xu LF, Wen P, Wen JB and Xiao XZ: Cost-effectiveness of lamivudine, telbivudine adefovir dipivoxil and entecavir on decompensated hepatitis B virus-related cirrhosis. Eur Rev Med Pharmacol Sci 20: 866-872, 2016

7. Zhou Y, Zhang $\mathrm{H}$ and Li Y: IL-35 expression in peripheral blood CD4(+) T cells from chronic hepatitis B virus-infected patients directly correlates with virus load. Cytokine 73 : 169-175, 2015.

8. Wang XL, Ren JP, Wang XQ, Wang XH, Yang SF and Xiong Y: Mutations in pre-core and basic core promoter regions of hepatitis B virus in chronic hepatitis B patients. World J Gastroenterol 22: 3268-3274, 2016.

9. Heymann F and Tacke F: Immunology in the liver - from homeostasis to disease. Nat Rev Gastroenterol Hepatol 13: 88-110, 2016.

10. Gummow J, Li Y, Yu W, Garrod T, Wijesundara D, Brennan AJ, Mullick R, Voskoboinik I, Grubor-Bauk B and Gowans EJ: A multiantigenic DNA vaccine that induces broad hepatitis $C$ virus-specific T-cell responses in mice. J Virol 89: 7991-8002, 2015.

11. Chen Y, Huang Z, Ma D, Chen L, Lai Q, Huang X, Zhou J, Zhang X, Ma Q, Chen Z, et al: Involvement of soluble scavenger receptor $\mathrm{A}$ in suppression of $\mathrm{T}$ cell activation in patients with chronic hepatitis B. BMC Immunol 16: 29, 2015.

12. Bull RA, Leung P, Gaudieri S, Deshpande P,Cameron B, Walker M, Chopra A, Lloyd AR and Luciani F: Transmitted/founder viruses rapidly escape from $\mathrm{CD} 8^{+} \mathrm{T}$ cell responses in acute hepatitis $\mathrm{C}$ virus infection. J Virol 89: 5478-5490, 2015.

13. Yang HC and Kao JH: Viral hepatitis. HBV cure - can we pin our hopes on immunotherapy? Nat Rev Gastroenterol Hepatol 12: 129-131, 2015.

14. Koh S and Bertoletti A: Circumventing failed antiviral immunity in chronic hepatitis B virus infection: triggering virus-specific or innate-like T cell response? Med Microbiol Immunol (Berl) 204: 87-94, 2015.

15. Holz $\mathrm{L}$ and Rehermann B: T cell responses in hepatitis $\mathrm{C}$ virus infection: historical overview and goals for future research. Antiviral Res 114: 96-105, 2015.

16. Raziorrouh B, Sacher K, Tawar RG, Emmerich F, NeumannHaefelin C,Baumert TF, Thimme R and Boettler T: Virus-specific $\mathrm{CD}^{+} \mathrm{T}$ cells have functional and phenotypic characteristics of follicular T-helper cells in patients with acute and chronic HCV infections. Gastroenterology 150: 696-706, 2016.

17. Wang Y, Liu S, Chen YU, Zheng S, Zhou LI, Hua T, Sui S, Lu F and Duan Z: Evolution of entecavir-resistant hepatitis B virus during entecavir and adefovir dipivoxil combination therapy. Exp Ther Med 11: 117-123, 2016.

18. Li X, Jie Y, You X, Shi H, Zhang M, Wu Y, Lin G, Li X, Gao Z and Chong Y: Optimized combination therapies with adefovir dipivoxil (ADV) and lamivudine, telbivudine, or entecavir may be effective for chronic hepatitis B patients with a suboptimal response to ADV monotherapy. Int J Clin Exp Med 8: 21062-21070, 2015. 